\title{
STUDIES IN OXYGEN THERAPY
}

\section{III, IN AN EXTREME TYPE OF SHALLOW BREATHING OCCURRING IN LETHARGIC ENCEPHALITIS *}

\author{
ALVAN L. BARACH, M.D.
} AND

MARGARET N. WOODWELL, A.B. BOSTON

The effects of oxygen inhalation on types of anoxemia frequently present in clinical disease, as those associated with cardiac insufficiency and pneumonia, have been described in Papers I and II of this series. The terminal development in two cases of lethargic encephalitis of a rare type of shallow breathing resulted in sudden extreme arterial anoxemia and carbon dioxid retention in arterial and venous blood. The effects of oxygen inhalation on the blood gases and on the clinical signs are reported in this paper.

\section{REPORT OF CASES}

CASE 25 (Table 2).-M. S., white, male, auto repairer; age, 25 years.

Diagnosis.-Lethargic encephalitis.

History.-Two weeks before entry, patient had right temporal headache. This was followed by pains in both arms and across the abdomen. During the three days prior to admission he developed fever, insomnia, blurring of vision and dropping of left eyelid.

Physical Examination. - Jan. 8, 1921: Temperature, 101 F.; pulse, 115; respiration, 25. Slight ptosis of both eyes, diplopia, weakness of left internal rectus muscle. Lungs clear and resonant. Heart not enlarged, no murmurs. Reflexes not abnormal. Urine negative. White blood cells, 11,100; polymorphonuclears, 79 per cent. Lumbar puncture revealed clear fluid under increased pressure; cells, 44; polymorphonuclears 14 and mononuclears 30 : alcohol positive, ammonium sulphate negative, Wassermann negative.

Course and Treatment.-Jan. 10, 1921. At 1 a. m. he became suddenly dyspneic and cyanotic; temperature rose to $103 \mathrm{~F}$; pulse to 140 ; respiration to 48 . At $10 \mathrm{a}$. $\mathrm{m}$. he was comatose, deep and superficial reflexes could not be obtained, neck was stiff, the extremities were limp and flaccid. No Kernig was present, no Babinski or ankle clonus. Lungs clear and resonant throughout. He breathed in a rapid jerky manner; at each inspiration the upper abdomen underwent a double convulsive contraction with a simultaneous twitching of the neck muscles but without any movement of the intercostal muscles during either phase of respiration. His face was of a dusky grayish color, the lips deeply cyanotic, the nail-beds a light blue color. Oxygen had been administered during the night through a funnel held close to the nose, without alleviation of the cyanosis in any degree. The mask of the rebreathing apparatus was applied with a valve adjustment, giving about an 80 per cent. oxygen

\footnotetext{
* From the Medical Service of the Massachusetts General Hospital. This paper is No. 17 of a series of studies of the physiology and pathology of the blood from the Harvard Medical School and allied hospitals.

* The expense of this work was, in part, defrayed by a grant from the Proctor Fund of Harvard University for the study of chronic diseases.
} 
mixture. It was then noticed that the rebreathing bag barely moved, and that an extreme type of shallow breathing was the cause of the cyanosis. This was in marked contrast to the convulsive movements of the upper abdomen, which suggested moderately deep breathing. At the end of five minutes a slight diminution of the cyanosis became noticeable; at the end of ten minutes it was strikingly diminished; after twenty-five minutes there was no cyanosis of face, fingers or mucous membranes, the nails were pink, the ears a rosy red, the lips free from any blueness. At the same time, the respiratory rate decreased from 45 to 34 and the pulse from 141 to 105 and later to 98 . The extreme shallow character of the respiration persisted unchanged, but the spasmodic movements of the diaphragm had largely disappeared. The neck was no longer stiff. All the reflexes persisted absent.

TABLE 1.-- Effect of Oxygen Inhalation on Pulse, Respiration and Cyanosis in Extreme Shallow Breathing in Case 25

\begin{tabular}{|c|c|c|c|c|}
\hline \multicolumn{2}{|c|}{ Time } & Pulse & Respiration & Cyanosis \\
\hline $\begin{array}{r}10: 25 \\
10: 35 \\
10: 45 \\
10: 55 \\
11: 00 \\
11: 20 \\
11: 28 \\
11: 33 \\
11: 38 \\
11: 43 \\
11: 55 \\
12: 02 \\
12: 09 \\
12: 26 \\
12: 34 \\
12: 53 \\
12: 56 \\
1: 00 \\
1: 05 \\
1: 10 \\
1: 16 \\
1: 23 \\
1: 35 \\
1: 45 \\
2: 00 \\
2: 20\end{array}$ & 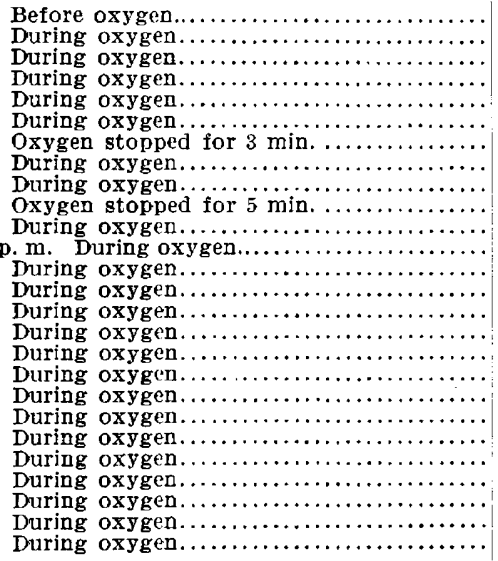 & $\begin{array}{r}141 \\
132 \\
120 \\
105 \\
98 \\
112 \\
126 \\
114 \\
114 \\
141 \\
132 \\
126 \\
123 \\
124 \\
129 \\
126 \\
126 \\
140 \\
129 \\
130 \\
120 \\
124 \\
128 \\
140 \\
140 \\
140\end{array}$ & $\begin{array}{l}45 \\
\ddot{3} \\
\ddot{38} \\
\ddot{40} \\
\ddot{34} \\
\ddot{0} \\
\ddot{44} \\
40 \\
\ddot{40} \\
42 \\
\ddot{2} \\
\ddot{39} \\
\ddot{39} \\
\ddot{40} \\
\ddot{40} \\
\ddot{40}\end{array}$ & $\begin{array}{c}+++ \\
++ \\
+ \\
0 \\
0 \\
0 \\
++ \\
+ \\
0 \\
+++ \\
++ \\
+ \\
+ \\
+ \\
++ \\
++ \\
++ \\
++ \\
++ \\
++ \\
++ \\
++ \\
++ \\
+++ \\
+++ \\
+++\end{array}$ \\
\hline
\end{tabular}

The inhalation of oxygen relieved the arterial anoxemia and resulted in a striking slowing of the pulse. The withdrawal of oxygen caused a simultaneous increase in the anoxemia and in the pulse rate. The arterial oxygen saturation was raised from 60.7 to 84.5 per cent. in forty-five minutes. The arterial carbon dioxid content in that time mounted from 64.2 volume per cent. to 88.4 volume per cent, indicating a steadily increasing carbonic acidosis. Failure of the circulation finally occurred, and accounted for the reappearance of the cyanosis.

The oxygen saturation of the arterial blood before the inhalation was 60.7 per cent.; the venous saturation was 46.4 per cent.; the arterial carbon dioxid content, 64.2 volume per cent.; the venous carbon dioxid content, 68.4 volume per cent. After oxygen had been given for forty-five minutes, the arterial saturation was 84.5 per cent.; the arterial carbon dioxid content, 88.4 volume per cent.; after fifty-five minutes the venous saturation was 87.9 per cent.; the venous carbon dioxid content, 88.6 volume per cent. When oxygen had been given for one hour it was stopped for three minutes. The cyanosis returned and the pulse began to climb, reaching 126. Oxygen was recommenced and given for five minutes, when the tank gave out. Pulse was then 114. It was five minutes before another tank had been secured, and in the meantime pulse rose to 141 , respiration to 44 , color changed to deep cyanosis of lips and finger nails. Oxygen was begun again but with less relief than formerly. Pulse slowed to 126 after the first hour and then gradually became elevated and feeble. Cyanosis increased moderately as circulation began to fail. After three more hours oxygen was stopped and patient died three minutes later in deep cyanosis. (See Table 1 for effect on pulse and respiratory rates.) 
CASE 26 (Table 2).-E. D., white, houséwife; age, 23 years.

Diagnosis.-Lethargic encephalitis.

History.-Ten days before entry an aching pain appeared behind right ear. Headache persisted up to time of admission, confined to right temporal region and variable in severity. She developed pains in chin, neck and shoulder blades. When the pains in the shoulders occurred respiration became very rapid and jerky (husband's statement). For seven days blurred vision and diplopia were present. Felt sleepy but found it difficult to go to sleep.

Physical Examination.-Jan. 23, 1921: Temperature, 101 F.; pulse, 130; respiration, 40. Double ptosis, double facial paralysis. Fields of vision limited in both eyes. Right leg twitches involuntarily. Knee-jerks not obtained. No other abnormal reflexes. Heart and lungs not abnormal. Urine negative. White blood cells, 11,200; polymorphonuclears, 75 per cent. Blood Wassermann, negative. Nonprotein nitrogen $53.1 \mathrm{mg}$. per 100 c.c. Spinal fluid under increased pressure, 20 cells, 14 polymorphonuclears and 6 lymphocytes. Alcohol negative. Ammonium sulphate negative. Culture sterile. Wassermann negative.

TABLE 2--Effect of Oxygen Inhalation on the Blood Gases in Extreme Shallow Respiration Occurring in Two Cases of LETHARGIC ENCEPHALITIS

\begin{tabular}{|c|c|c|c|c|c|c|c|c|c|c|c|}
\hline \multirow[b]{2}{*}{$\begin{array}{l}\text { Case } \\
\text { No. }\end{array}$} & \multirow[b]{2}{*}{ Diagnosis } & \multirow[b]{2}{*}{$\begin{array}{l}\text { Date, } \\
1921\end{array}$} & \multirow[b]{2}{*}{$\begin{array}{c}\text { Oxygen } \\
\text { Inhalation }\end{array}$} & \multicolumn{2}{|c|}{$\begin{array}{c}\text { Oxygen } \\
\text { Content }\end{array}$} & \multicolumn{2}{|c|}{$\begin{array}{c}\text { Oxygen } \\
\text { Saturation }\end{array}$} & \multirow{2}{*}{$\begin{array}{l}\text { Oxygen } \\
\text { Capac- } \\
\text { ity } \\
\text { Vol. } \\
\%\end{array}$} & \multirow{2}{*}{$\begin{array}{c}\text { Hemo- } \\
\text { globin } \\
\text { Calcu- } \\
\text { lated } \\
\text { from } \\
\text { Oxygen } \\
\text { Capac- } \\
\text { ity }\end{array}$} & \multicolumn{2}{|c|}{$\begin{array}{c}\text { Carbon Dioxid } \\
\text { Content }\end{array}$} \\
\hline & & & & $\begin{array}{c}\text { Arte- } \\
\text { rial } \\
\text { Vol. } \\
\%\end{array}$ & $\begin{array}{c}\text { Ve- } \\
\text { nous } \\
\text { Vol. } \\
\%\end{array}$ & $\begin{array}{c}\text { Arte- } \\
\text { rial } \\
\%\end{array}$ & $\underset{\substack{\text { Ve- } \\
\text { nous }}}{ }$ & & & $\begin{array}{l}\text { Arte- } \\
\text { rial } \\
\text { Vol. } \\
\text { \% }\end{array}$ & $\begin{array}{c}\text { Ve- } \\
\text { nous } \\
\text { VoI. } \\
\%\end{array}$ \\
\hline 26 & $\begin{array}{l}\text { Lethargic } \\
\text { encepha- } \\
\text { litis }\end{array}$ & $1 / 10$ & $\begin{array}{c}\text { Before } \\
\text { oxygen } \\
\text { Oxygen for } \\
1 \text { hr. } 30 \mathrm{~min} \text {. } \\
\text { Oxygen for } \\
1 \text { hr. } 40 \text { min. } \\
\text { Before } \\
\text { oxygen } \\
\text { Oxygen for } \\
45 \text { min. }\end{array}$ & $\begin{array}{l}14.74 \\
20.29 \\
\ldots \ldots \\
13.76 \\
17.44\end{array}$ & $\begin{array}{l}11.29 \\
\ldots \ldots \\
21.37 \\
\ldots \ldots \\
\ldots .\end{array}$ & $\begin{array}{l}60.7 \\
84.5 \\
\ldots \ldots \\
64.5 \\
88.0\end{array}$ & $\begin{array}{c}46.4 \\
\ldots \\
87.9\end{array}$ & $\begin{array}{c}24.30 \\
(24.30) \\
(24.30) \\
21.31 \\
(21.31)\end{array}$ & $\begin{array}{c}131.2 \\
(131.2) \\
\ldots \ldots \\
115.0 \\
(115.0)\end{array}$ & $\begin{array}{l}64.2 \\
88.4+ \\
\ldots \ldots \\
51.0 \\
62.0\end{array}$ & $68.4^{*}$ \\
\hline
\end{tabular}

The oxygen saturation of the arterial and venous blood was raised. The carbon dioxid content of the blood steadily increased.

* Carbon dioxid dissociation curve showed an acidosis.

$t$ This value is approximate because the combined gases were above the calibrated portion of the pipet.

Course and Treatment.-Jan. 25, 1921. Temperature, 102.5 F.; pulse, 140; respiration, 45. At 7:30 a. m., patient went into coma, became cyanotic and breathed in a rapid, jerky manner. Lips and ears showed moderate cyanosis, the finger nails very marked cyanosis. Moist râles present at right base. Pulse of poor quality, rate 141 . Oxygen was given through a mask with valve attachment providing about an 80 per cent. oxygen mixture for three hours. The first effect noticeable was a definite slowing of the pulse. In three minutes it slowed from 141 to 132 ; in fifteen minutes it had attained its maximal slowing, 114; after this the pulse rose and showed only slight or temporary periods of slowing. The cyanosis began to diminish in five minutes and became progressively less for twenty minutes; at that time there was just a slight bluish tinge to the nail beds which never wholly disappeared. Respirations continued very shallow and rapid, rate from 45 to 50 . The cyanosis remained minimal for the first hour, increased in the second hour and was marked in the third hour. Whenever the oxygen was removed she became darkly cyanotic. (The persistence of the cyanosis in the presence of a rich oxygen mixture seemed due to the exceptional shallowness of the respiration and the stagnant circulation.) After three hours' oxygen the inhalation was 
stopped and the patient died two minutes later. Ten minutes previous, $25 \mathrm{gm}$. sodium bicarbonate were given intravenously without effect.

The arterial oxygen saturation before the inhalation was 64.5 per cent.; after forty-five minutes, 82 per cent. Arterial carbon dioxid content before was 51 volume per cent.; after, 62 volume per cent. The carbon dioxid dissociation curve before oxygen showed a marked uncompensated carbon dioxid acidosis, $p_{\mathrm{H}} 7.22$.

In both these cases the soda-lime was tested before and after using and found perfect for absorption of carbon dioxid.

In these two cases shallow breathing was the direct cause of a very marked arterial anoxemia. Because of the convulsive movements of the diaphragm the extreme shallowness of the respiration was not actually appreciated until the mask was applied, when it was noticed that the rebreathing bag barely moved. Interpretation of this unique phenomenon in lethargic encephalitis cannot be made with certainty as necropsies were not obtained. It seems probable, however, that the respiratory center in the medulla became involved in the inflammatory process, since lesions in the bulb are quite common in this disease.

Shallow breathing has been shown to be a cause of anoxemia by producing uneven ventilation of the lungs, and consequently incomplete oxygenation of the blood. ${ }^{1}$ This is based on the conception of Keith ${ }^{2}$ that expansion of the lungs takes place in a manner resembling the opening of a Japanese fan, the peripheral portions expanding first and the root region last. In these cases the total ventilation itself was so small that it was the air in the trachea and bronchi that became chiefly renewed and the alveolar air only secondarily changed.

The effects on the blood gases were first, a marked arterial anoxemia, and secondly, a retention of carbon dioxid in the arterial and venous blood. Oxygen therapy was able to increase greatly the arterial and venous oxygen saturation, but was powerless against the steady accumulation of carbon dioxid. In one case a carbon dioxid dissociation curve, done before oxygen was given, showed an uncompensated carbon dioxid acidosis, $P_{H}$ 7.22.

In the beginning, the circulation was strikingly improved as a result of the relief of the anoxemia. (Table 1 shows the parallel effect on the pulse and cyanosis of the inhalation of oxygen.) The subsequent failure of the circulation seemed dependent on the increasing carbon dioxid retention in the blood, which showed no disposition to decrease since the shallowness of respiration itself persisted. The final cyanosis was thus of stagnant origin.

1. Haldane, J. S.: Meakins, J. C., and Priestley, J. G.: The Effects of Shallow Breathing, J. Physiol. 52:433, 1919.

2. Keith, A.: Quoted from Haldane, J. S.; Meakins, J. C., and Priestley, I. G.: The Effect of Shallow Breathing, J. Physiol. 52:449, 1919. 
SUM MARY

1. In two patients with lethargic encephalitis the development of an extreme type of shallow breathing was attended with deep cyanosis and coma. The arterial blood was markedly deficient in oxygen and contained an excess of carbon dioxid.

2. Inhalation of oxygen greatly relieved the arterial anoxemia but was without effect on the steady accumulation of carbon dioxid. An uncompensated carbon dioxid acidosis, $p_{\mathrm{H}} 7.22$, was demonstrated in one case by a carbon dioxid dissociation curve.

3. The circulation was strikingly improved in the beginning as a result of the relief of the anoxemia. Later, progressive cardiac failure occurred, apparently related to the carbon dioxid retention.

4. It is evident that shallow respiration, if extreme, interferes not only with oxygen absorption but with carbon dioxid elimination.

5. It seems probable that a terminal involvement of the respiratory center in lethargic encephalitis is at times the cause of death. 